\title{
KEMAMPUAN KOMUNIKASI MATEMATIK SISWA SMP KELAS IX PADA MATERI BANGUN RUANG SISI DATAR DI KABUPATEN BANDUNG
}

\author{
Fitria Noviana $^{1}$, Sigit Mulqiyono $^{2}$, M. Afrilianto ${ }^{3}$ \\ 1,2,3 IKIP Siliwangi, J1. Terusan Jenderal Sudirman, Cimahi, Jawa Barat, Indonesia \\ ${ }^{1}$ meong.fitria@gmail.com, ${ }^{2}$ Mulqiyonosigit0@gmail.com, ${ }^{3}$ muhammadafrilianto1@ikipsiliwangi.ac.id
}

\begin{abstract}
Students mastery of mathematical communication ability can be one of benchmark to know the level of students understanding about the material that has been submitted. Mathematics is not only a tool for thinking but also math can be a tool to communicate an idea. This research aim is to describe the mathematical communication ability of class IX SMP. The research takes place in one of SMP in Bandung Regency. The mathematics material that discussed is about polyhedron. Data were taken from the results of the test instrument about the ability of mathematics communication. The samples that researcher used are about 30 students of class IX SMP. The results of this research showed the percentage of students' mathematics communication ability at $31 \%$ that means most of the students have a low percentage of understanding mathematics communication.
\end{abstract}

Keywords: Mathematical Communication, Polyhedron

\begin{abstract}
Abstrak
Penguasaan kemampuan komunikasi matematik siswa dapat dijadikan salah satu tolak ukur tingkat pemahaman yang siswa miliki terhadap materi yang telah disampaikan. Tujuan penelitian ini ialah untuk mendeskripsikan kemampuan komunikasi matematik siswa kelas IX SMP di salahsatu SMP di Kabupaten Bandung terhadap materi bangun ruang sisi datar. Data diperoleh dari hasil tes instrumen berupa 4 butir soal kemampuan komunikasi matematik dengan sampel yang diambil sebanyak 30 orang siswa kelas IX SMP. Persentase pencapaian kemampuan komunikasi siswa yang didapatkan dari hasil observasi sebesar sebesar 31\% yang berarti kemampuan komunikasi matematik siswa tersebut masih rendah.

Kata Kunci: Komunikasi Matematik, Bangun Ruang Sisi Datar
\end{abstract}

How to cite: Noviana, F., Mulqiyono, S., \& Afrilianto, M. (2018). Kemampuan Komunikasi Matematik Siswa SMP Kelas IX pada Materi Bangun Ruang Sisi Datar di Kabupaten Bandung. JPMI - Jurnal Pembelajaran Matematika Inovatif, 1 (4), 583-590.

\section{PENDAHULUAN}

Berdasarkan hasil survey yang dilakukan oleh Programme for International Student Assessment (PISA) tahun 2012, menyatakan bahwa kemampuan peserta didik Indonesia dalam matematika berada pada peringkat 64 dari 65 negara (Afrilianto \& Rosyana, 2016). Rendahnya minat siswa terhadap mata pelajaran matemaika menjadi salah satu penyebab rendahnya hasil belajar siswa pada saat ini. Penggunaan metode pembelajaran konvensional dalam menyampaikan materi di kelas pun mempengaruhi rendahnya kemampuan siswa dalam 
bermatematika,sehingga membatasi siswa untuk mengeksplorasi pengetahuan yang mereka miliki. Menurut Ruseffendi (Elida, 2012) pengetahuan yang dimiliki siswa dalam mempelajari matematika di kelas diperoleh dengan cara pemberitahuan dari guru, tidak melalui suatu kegiatan eksplorasi. Sejalan dengan itu NCTM (dalam Afrilianto, 2014) merekomendasikan agar pembelajaran matematika sekolah menengah memuat tugas memformulasi masalah matematika berdasarkan beragam situasi baik dalam matematika atau di luar matematika, tugas menyusun dan menemukan konjektur, serta belajar menggeneralisasi dan memperluas masalah melalui pengajuan masalah berikutnya.

Salah satu cara untuk menumbuh kembangkan kemampuan komunikasi, pemahaman, dan kemandirian belajar adalah dengan melatih siswa mengerjakan soal-soal yang berhubungan dengan keterampilan tersebut (Tandilling, 2012). Tidak dapat dipungkiri bahwa sebagian besar guru matematika jarang memberikan soal-soal matematika kepada siswanya dalam bentuk non-rutin. Guru hanya terpaku pada soal-soal rutin yang hanya melatih siswa secara mekanistik dan sifatnya teks book. Peran guru dalam pembelajaran bukan sekedar sebagai pelantara dalam menyampaikan informasi saja tetapi juga sebagai pendorong bagi siswa untuk mengontruksikan pengetahuan yang siswa miliki dengan cara mengomunikasikan gagasan yang dimiliki. Peran guru dalam pembelajaran matematika konfensional yang terlalu mendominasi tidak memberi kesempatan bagi siswa untuk mengkontruksikan pengetahuan yang mereka miliki. Sedangkan menurut NCTM (Anita, 2014), menjelaskan bahwa dalam pembelajaran matematika ada 5 kemampaun matematik yang perlu dikuasai oleh siswa yaitu: kemampuan pemecahan masalah (problem solving), kemampuan penalaran (reasoning), kemampuan komunikasi (communication), kemampuan koneksi (connection), dan kemampuan representasi (representation).

Sebagai salah satu kemampuan matematik yang perlu dikuasai oleh siswa ialah kemampuan komunikasi. Menurut (Afrilianto, 2015) Kemampuan komunikasi tidak terlepas dari pengertian matematika itu sendiri yaitu bahasa simbolik yang memungkinkan terjadinya transfer informasi yang padat makna, tidak mendua arti dan bersifat universal. Penguasaan kemampuan komunikasi dapat menjadi salah satu tolak ukur tingkat pemahaman siswa pada materi yang telah disampaikan. Adapun dua alasan yang dikemukakan oleh Barody (Choridah, 2013) mengapa kemampuan komunkasi matematik perlu untuk dikuasai oleh siswa, yaitu: (1) mathematics as language, maksudnya matematika bukan hanya sesekedar alat bantu untuk berfikir akan tetapi matematika pun dapat menjadi alat untuk mengkomunikasikan suatu gagasan dengan tepat dan jelas dan (2) mathematics is learning as social activity, maksudnya adalah matematika sebagai salah satu aktivitas sosial. Hal tersebut senada dengan yang dikemukakan oleh Freudenthal bahwa matematika merupakan bagian dari aktifitashumanis.

Adapun indikator dari kemampuan komunikasi matematik menurut Sumarmo (Hendriana, Rohaeti, \& Sumarno, 2017): a) Menyatakan benda-benda nyata, situasi, dan peristiwa seharihari dalam bentuk model matematika (gambar, tabel, diagram, grafik, atau ekspresi aljabar), b) Menjelaskan ide, dan model matematika ke dalam bahasa sendiri, c) Menjelaskan dan membuat pertanyaan matematika yang dipelajari, d) Mendengarkan, berdiskusi dan menulis tentang matematika, e) Membaca dengan pemahaman suatu presentasi tertulis, f) Membuat konjektur, menyusun argumen, merumuskan definisi dan generalisasi. 
Mencermati uraian diatas penulis tertarik untuk melaksanakan sebuah observasi awal untuk mengetahui kesulitan-kesulitan apa saja yang dihadapi siswa dalam mengerjakan soal kemampuan komunikasi serta untuk mengukur tingkat penguasaan kemampuan komunikasi matematik siswa kelas IX disalah satu SMP di Kabupaten Bandung pada materi bangun ruang sisi datar.

\section{METODE}

Metode penelitian yang diambil ialah metode kualitatif. Penggunaan metode kualitatif bertujuan untuk mendeskripsikankan penguasaan kemampuan komunikasi matematik siswa kelas IX pada meteri bangun ruang sisi datar. Teknik dalam pemilihan subjek penelitian ini adalah teknik purposive sampling yaitu pengambilan sampel dengan tujuan untuk lebih memfokuskan penelitian terhadap subjek tersebut, dimana data yang didapatkan lebih dalam dan akurat (Sugiyono, 2010). Dalam penelitian ini30 orang siswa kelas IX disalah satu SMP di Kabupaten Bandung diambil sebagai sampel. instrumen penelitian yang digunakan berupa 4 butir soal kemampuan komunikasi matematik.

Untuk pedoman pembemberian skor pada tiap butir soal kemampuan komunikasi matematis tersebut maka pemberian skor berpedoman pada Holistic Scoring Rubrics yang dikemukakan oleh Cai, Lane dan Jakabcsin (Merdilani, 2015).

Tabel 1.Kriteria Penskoran Kemampuan Komunikasi Matematik

\begin{tabular}{|c|c|}
\hline Skor & Kriteria Jawaban dan Alasan \\
\hline 4 & Penjelasan secara matematis, lengkap, jelas dan benar. \\
\hline 3 & $\begin{array}{l}\text { Penjelasan secara matematis, hampir lengkap, melukiskan gambar, penggunaan } \\
\text { algoritma secara lengkap dan benar, namun terdapat sedikit kesalahan. }\end{array}$ \\
\hline 2 & $\begin{array}{l}\text { Penjelasan secara matematik masuk akal, namun hanya sebagian yang benar,melukis } \\
\text { gambar namun kurang lengnkap, dan membuat model matematika dengan } \\
\text { benarnamun salah dalam mendapatkan solusi. }\end{array}$ \\
\hline 1 & Hanya sedikit dari penjelasan gambar atau model matematika yang benar. \\
\hline 0 & Tidak ada jawaban atau salah menginterpretasikan \\
\hline
\end{tabular}

Adapun indikator komunikasi pada tiap butir soal yang diujikan ialah sebagai berikut:

Tabel 2. Indikator Kemampuan Komunikasi Matematik

\begin{tabular}{cl}
\hline No & \\
Soal & \\
\hline 1 & Membuat konjektur, meyusun argumen, merumuskan definisi dan generalisasi. \\
2 & Menjelaskan dan membuat pertanyaan matematika yang dipelajari. \\
3 & $\begin{array}{l}\text { Menjelaskan ide, dan model matematika (gambar, tabel, diagram, grafik, ekspesi } \\
\text { aljabar). }\end{array}$ \\
4 & $\begin{array}{l}\text { Menyatakan benda-benda nyata, situasi dan peristiwa sehari-hari ke dalam bentuk } \\
\text { model matematika (gambar, tabel, diagram, grafik, ekspesi aljabar). }\end{array}$ \\
\hline
\end{tabular}




\section{HASIL DAN PEMBAHASAN}

\section{Hasil}

Tabel 3 merupakan acuan persentase ketercapaian kemampuan komunikasi matematik terhadap hasil kerja siswa, sehingga penilaian yang diberikan dapat diukur dengan baik.

Tabel 3. Kategori Pencapaian Kemampuan Komunikasi Matematis Siswa

\begin{tabular}{cc}
\hline Persentase pencapaian Kemampuan Komunikasi Matematis & Kategori \\
\hline$\leq 33$ & Rendah \\
$33>65,9$ & Sedang \\
$66>100$ & Tinggi \\
\hline
\end{tabular}

Berdasarkan hasil uji instrumen kemampuan komunikasi matematik pada materi bangun ruang sisi datar terhadap siswa kelas IX pada salah satu SMP di Kabupaten Bandung didapatkan hasil sebagai berikut:

Tabel 4. Hasil Uji Tes Kemampuan Komunikasi Matematik Siswa

\begin{tabular}{cccccc}
\hline & \multicolumn{4}{c}{ Skor untuk tiap butir soal } & Skor \\
\cline { 2 - 5 } & $\mathbf{x 1}$ & $\mathbf{x 2}$ & $\mathbf{x 3}$ & $\mathbf{x 4}$ & Total (Y) \\
\hline Jumlah & 43 & 36 & 48 & 23 & 150 \\
Rata - rata & 1,43 & 1,2 & 1,6 & 0,77 & 5 \\
Persentase & $36 \%$ & $30 \%$ & $40 \%$ & $19 \%$ & $31 \%$ \\
\hline
\end{tabular}

Dari keseluruhan butir soal yang diujikan kepada siswa, persentase keberhasilan kemampuan komunikasi siswa SMP sebesar 31\% sebagaimana yang terlihat pada tabel 3 . Hal tersebut menunjukan bahwa tingkat ketercapaian siswa terhadap kemampuan komunikasi matematik masih tergolong rendah. Dengan persentase terbesar untuk tiap butir soal berada pada soal no. 3 dengan indikator "Menjelaskan ide, dan model matematika (gambar, tabel, diagram, grafik, ekspesi aljabar)" yaitu sebesar $40 \%$ dan persentase terkecil berada pada soal no. 4 dengan indikator "Menyatakan benda-benda nyata, situasi dan peristiwa sehari-hari ke dalam bentuk model matematika (gambar, tabel, diagram, grafik, ekspesi aljabar)" sebesar 19\%.

\section{Pembahasan}

Kemampuan komunikasi matematik memiliki peran penting sebagai representasi kemampuan pemahaman siswa terhadap konsep matematik, masalah sehari-hari, dan konsep dalam disiplin ilmu lain (Hidayat, \& Sumarmo, 2013; Rahmi, Nadia, Hasibah, \& Hidayat, 2017; Zakiah, Saomi, Syara, Hidayat, \& Hendriana, 2018). Faktor penyebab ketidakberhasilan belajar yang berimbas pada lemahnya kemampuan komunikasi matematik siswa mungkin saja dari ketidaktepatan penyajian ataupun metode pengajarannya (Afrilianto, 2015). Salah satu cara untuk menumbuhkembangkan kemampuan komunikasi, pemahaman, dan kemandirian belajar adalah dengan melatih siswa mengerjakan soal-soal yang berhubungan dengan keterampilan tersebut. Perlu adanya standar soal-soal yang dapat mengukur ketrampilan komunikasi dan pemahaman tingkat tinggi agar siswa dapat berpikir kritis dan kreatif (Tandilling, 2012). Soal intrumen kemampuan komunikasi matematik dalam penelitian ini bertujuan untuk mengetahui kesulitan - kesulitan apa saja yang dihadapi oleh siswa dalam 
mengerjakan soal yang berkaitan dengan kemampuan komunikasi matematik, berikut disajikan analisis terhadap kesulitan-kesulitan yang peneliti temukan.

\section{Soal no. 1}

Diketahui sebuah kubus ABCD.EFGH mempunyai panjang rusuk $7 \mathrm{~cm}$. Diagonal AC dan EG sejajar serta membentuk bidang ACGE.

a. Bagaimana panjang diagonal EG dan AC ?

b. Bangun apakah bidang ACGE dan berikan alasanya

c. Tentukan luas daerah ACGE

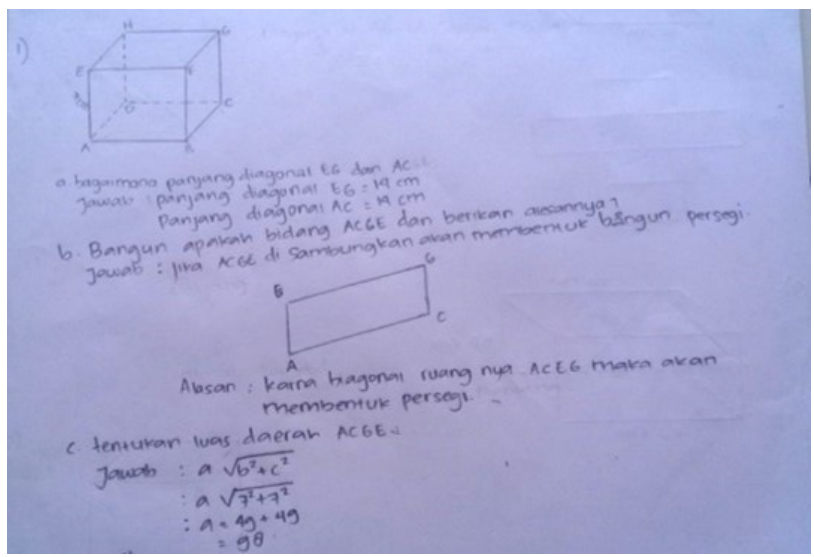

Gambar 1.Jawabansiswa untuksoal no1

Dengan indikator membuat konjektur, menyusun argumen, merumuskan definisi dan generalisasi, persentase pencapaian kemampuan komunikasi siswa sebesar 36\% termasuk dalam kategori sedang. Kesulitan yang siswa hadapi dalam menyelesaaikan soal no.1 ialah siswa masih kurang menguasai dan memahami konsep dasar cara mencari panjang diagonal ruang dan diagonal bidang pada kubus. Terlihat dari jawaban siswa pada jawaban poin (a), siswa tersebut menjawab dengan menjumlahkan panjang dari rusuk kubus yang seharusnya panjang diagonal ruang dan bidang kubus bisa dicari dengan menggunakan rumus pythagoras. Pada jawaban poin (b) pun siswa mengalami kesulitan untuk menjelaskan definisi dari persegipanjang dan pada poin (c) siswa siswa malah menghitung dengna menggunakan rumus Pythagoras untuk mencari luas daerah yang berbentuk persegi panjang.

\section{Soal no. 2}

Perhatikan gambar di bawah ini !

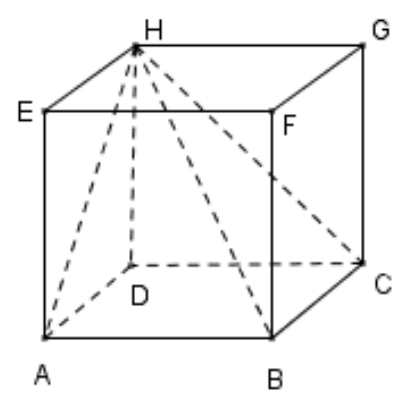

Gambar 2, Soal No 2 
Coba kamu tambahkan informasi atau ukuran pada gambar di atas kemudian susunlah suatu permasalahan atau pertanyaan yang relevan, kemudian selesaikan pertanyaan yang kamu buat tersebut!

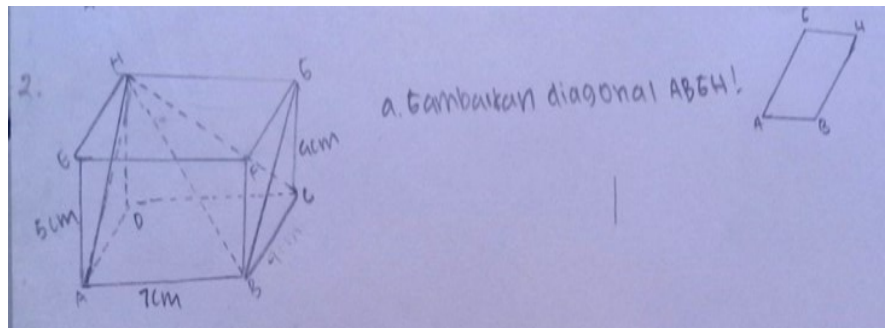

Gambar 3.Jawaban Siswa Untuk Soal No 2

Indikator soal no 2 ialahmenjelaskan dan membuat pertanyaan matematika yang dipelajari, persentase pencapaian kemampuan komunikasi siswa sebanyak 30\% termasuk dalam kategori rendah.Analisis soal no. 2 siswa diminta untuk membuat pertanyaan yang sesuai dengan gambar yang diberikan dan diharapkan siswa bisa untuk menjelaskan proses atau alasan dari jawaban yang mereka buat. Namun pada jawaban siswa pada terlihat siswa kurang begitu memahami maksud dari soal yang diberikan. Siswa menbuat penyataan yang tidak sesuai dengan soal yang diberikan.

\section{Soal no. 3}

Ervan memiliki dus mainan berbentuk balok dengan ukuran panjang, lebar dan tinggi masingmasing $10 \mathrm{~cm}, 2 \mathrm{dm}$, dan 0,3 m. Jika Ervan ingin menutupi dusnya dengan kertas kado. Dapatkah kamu membantu Mirna untuk membuat jaring-jaring dus mainan yang pas untuk menutupi dus tersebut?

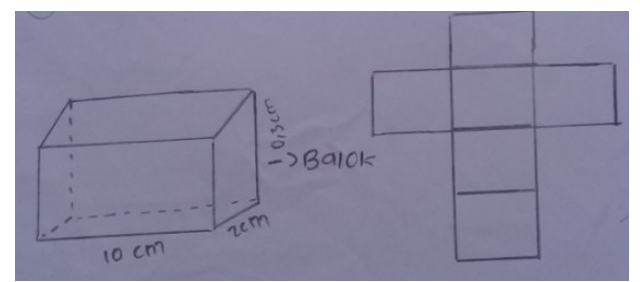

Gambar 4.Jawaban Siswa Untuk Soal No 3

Untuk soal no.3 indikator menjelaskan ide, dan model matematika (gambar, tabel, diagram, grafik, ekspesi aljabar), dengan persentase pencapaian kemampuan komunikasi siswa sebesar 40\% termasuk dalam kategori sedang, siswa diminta untuk membuat jaring - jaring balok. Pada gambar 4 terlihat siswa cukup mampu menggambarkan bentuk dari jaring - jaring balok akan tetapi didapat kan masih banyaksiswa yang kurang tepat saat menggambar dengan tidak susainya ukuran yang diminta.

\section{Soal no. 4}

Pak Tanu akan membuat kandang ayam yang berbentuk prisma segiempat dengan kerangka terbuat dari besi berukuran panjang $20 \mathrm{~cm}$, lebar $30 \mathrm{~cm}$, dan tinggi $40 \mathrm{~cm}$. Jika Pak Tanu memiliki bahan besi sepanjang 10 meter, dapatkah kamu membantu Pak Tanu menentukan jumlah kandang ayam yang dapat dibuat?

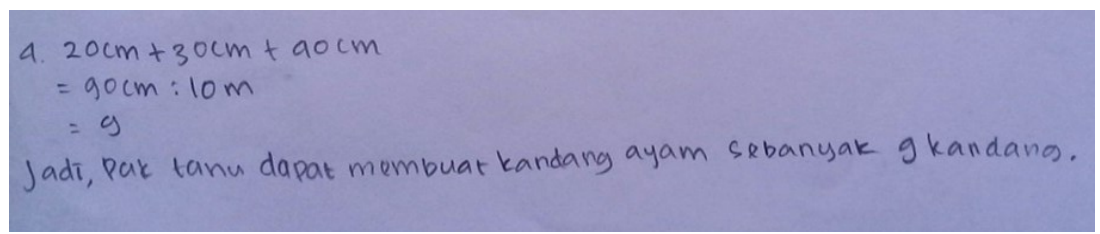

Gambar 5.Jawaban Siswa untuk Soal No 4 
Dengan persentase sebesar $19 \%$ indikator menyatakan benda-benda nyata, situasi dan peristiwa sehari-hari ke dalam bentuk model matematika (gambar, tabel, diagram, grafik, ekspesi aljabar) pada soal no.4 merupakan nilai pencapaian terkecil dari 4 indikator yang diujikan. Kesulitan yang siswa hadapi pada soal no 4 siswa masih belum terbiasa untuk menghubungkan peristiwa sehari-hari ke dalam ide matematika. Sehingga penyelesaian yang siswa berikanterlihat kurang sistematis.

Berdasarkan hasil analisis hasil uji dan pembahasan diatas terlihat bahawa penguasaan kemampuan komunikasi matematik siswa kelas IX pada salah satu SMP di Kabupaten Bandung masih tergolong rendah. Dengan nilai persentase untuk keseluruhan indikator sebesar sebesar 31\%Dengan persentase terbesar sebesar $40 \%$ untuk tiap butir soal no. 3 dengan indikator "Menjelaskan ide, dan model matematika (gambar, tabel, diagram, grafik, ekspesi aljabar)" dan persentase terkecil berada pada soal no. 4 dengan indikator "Menyatakan benda-benda nyata, situasi dan peristiwa sehari-hari ke dalam bentuk model matematika (gambar, tabel, diagram, grafik, ekspesi aljabar)" sebesar 19\%.

\section{KESIMPULAN}

Berdasarkan hasil penelitian ini dapat ditarik kesimpulan bahwa kemampuan komunikasi matematik siswa SMP masih rendah. Hal ini dapat dilihat dari hasil tes yang diberikan persentase pencapaian kemampuan komunikasi siswa terhada soal yang di berikan masih tergolong rendah $\leq 33 \% 33$ yaitu sebesar 31\%. Maka perlu adanya studi lanjutan untuk mengetahui permasalahan yang menyebabkan rendahnya kemampuan komunikasi tersebut serta dapat memberikan solusi untuk meninngkatkannya.

Salah satunya dengan cara menerapkan pembelajaran inovatif dan lebih interaktif sehingga siswa lebih memahami akan konsep matematika yang diajarkan, dimana siswa dapat merasakan secara langsung kegunaan belajar matematika didalam kehidupan sehari-hari sehingga konsep matematika dapat bertahan lama dalam ingatan siswa.

\section{UCAPAN TERIMA KASIH}

Terima kasih penulis ucapkan kepada pihak - pihak yang telah membantu dalam menyelesaikan penelitian ini, terutama kepada bapak M. Afrilianto, M.Pd selaku dosen pembimbing dan juga kepada IKIP Siliwangi yang telah memfasilitasi penulis dalam menyelesaikan jurnal ini.

\section{DAFTAR PUSTAKA}

Afrilianto, M. (2014). Strategi Formulate Share Listen Create Untuk Mengembangkan Kemampuan Mathematical Problem Posing Siswa SMP. Didaktik, 8, 21-28.

Afrilianto, M. (2015). Pengaruh Pendekatan Model-Eliciting Activities Terhadap Kemampuan Komunikasi Matematik Siswa SMP. P2M STKIP Siliwangi, 2(1), 40-45.

Afrilianto, M., \& Rosyana, T. (2017). Peningkatan Kemampuan Komunikasi Matematika Siswa SMP dengan Pendekatan Metaphorical Thinking (Volume 4,). Prosiding Seminar Nasional Matematika dan Pendidikan Matematika STKIP Siliwangi. 
Anita W. A. (2014). ). Pengaruh Pembelajaran Matematika Realistik Berbasis Kurikulum 2013 Terhadap Peningkatan Kemampuan Representasi Matematika Siswa SMP (Volume 2, p. 295). Bandung: Prosiding Seminar Nasional Pendidikan Matematika STKIP Siliwangi.

Choridah, D. T. (2013). Peran Pembelajaran Berbasis Masalah untuk Meningkatkan Kemampuan Komunikasi dan Berpikir Kreatif serta Disposisi Matematis Siswa SMA. Infinity Journal, 2(2), 1-9.

Elida, N. (2012). Meningkatkan Kemampuan Komunikasi Matematik Siswa Sekolah Menengah Pertama Melalui Pembelajaran Think-Talk-Write (TTW). Jurnal Infinity, 1(2), 178-185.

Hendriana, H., Rohaeti, E. E., \& Sumarno, U. (2017). Hard Skills Dan Soft Skills. Bandung: Refika Aditama.

Hidayat, W., \& Sumarmo, U. (2013). Kemampuan Komunikasi dan Berpikir Logis Matematika serta Kemandirian Belajar. dalam Jurnal Delta-fi, 2(1).

Merdilani, P. (2015). Meningkatkan Kemampuan Komunikasi Matematis Siswa SMP dengan Pendekatan Pendidikan Matemaika Realistik. Skripsi.

Rahmi, S., Nadia, R., Hasibah, B., \& Hidayat, W. (2017). The Relation between Self-Efficacy toward Math with the Math Communication Competence. Infinity Journal, 6(2), 177182.

Sugiyono. Dr. (2010). Metode Penelitian Pendidikan (Pendekatan Kuantitatif, Kualitatif dan $R \& D)$. Bandung: Alfabeta.

Tandilling, E. (2012). Pengembangan Instrumen untuk Mengukur Kemampuan Komunikasi Matematik, Pemahaman Matematik, Dan Self- Regulated Learning Siswa dalam Pembelajaran Matematika di sekolah Menengah Atas. Jurnal Penelitian Pendidikan, 13(1), 24-31.

Zakiah, L., Saomi, A. S. N., Syara, R., Hidayat, W., \& Hendriana, H. (2018). THE EFFICIENCY OF USING EDUCATION VIDEOS ON THE LINEAR PROGRAM MATERIAL AS OBSERVED IN VOCATIONAL HIGH SCHOOL STUDENTS'MATHEMATICAL COMMUNICATION ABILITY. Journal Of Educational Experts (JEE), 1(1), 11-18. 